\title{
AGRO-CLIMATIC ZONING TO BANANA-GROWING IN THE MESOREGION OF VALE DO RIO DOCE ${ }^{1}$
}

\author{
GEOVÁLIA OLIVEIRA COELHO², LUIZ ANTÔNIO DOS SANTOS DIAS ${ }^{3}$, \\ FERNANDO LUIZ FINGER ${ }^{4}$
}

\begin{abstract}
This study aims at identifying by zoning the mesoregion of Vale do Rio Doce edaphoclimatic aptitude for the commercial production of banana. The factors used in the agro-climatic zoning were temperature, altitude, rainfall, water deficit and soil type. Information on the thermal conditions was acquired from the INMET and also using estimates from a mathematical model. Altimetry data were acquired using digital elevation model generated from ASTER images. Rainfall data were collected from literature and from the ANA. To obtain the data of water deficit a standard water balance was calculated. Soil information was provided by Geominas Program. According to the results it was evident that banana can be grown with the use of irrigation in $28.7 \%$ of the zoned area (about $11,000 \mathrm{~km}^{2}$ ) emphasizing Guanhães, Mantena and Aimorés microregion. It was clear that $71.3 \%$ from the mesoregion is unsuitable to produce bananas because of the altitude and soil type. Moreover it was also clear that the mesoregion of Vale do Rio Doce has no preferential and suitable areas for the cultivation of unirrigated banana.
\end{abstract}

Index terms: Musa spp., zoning, mesoregion of Vale do Rio Doce.

\section{ZONEAMENTO AGROCLIMÁTICO PARA A CULTURA DA BANANA NA MESORREGIÃO VALE DO RIO DOCE - MG}

RESUMO - O objetivo desta pesquisa foi identificar, por meio de zoneamento, a aptidão edafoclimática da mesorregião do Vale do Rio Doce para a produção comercial de banana. Os fatores utilizados no zoneamento agroclimático foram temperatura, altitude, precipitação, deficiência hídrica e tipo de solo. As informações sobre as condições térmicas foram obtidas do Instituto Nacional de Meteorologia e por meio de estimativas de modelo matemático. Os dados altimétricos foram obtidos por meio do modelo digital de elevação, gerado a partir de imagens ASTER da mesorregião. Os dados de precipitação foram coletados da literatura e da Agência Nacional de Águas. Para a obtenção dos dados de deficiência hídrica, foi calculado o balanço hídrico normal. As informações de solo foram adquiridas do Programa GeoMinas. A pesquisa evidenciou que a bananeira pode ser cultivada com o uso de irrigação, em 28,7\% da área zoneada (1,1 milhão de hectares), com destaque para as microrregiões de Guanhães, Mantena e Aimorés. Por outro lado, 71,3\% da mesorregião são inaptas para o cultivo da banana, em função da altitude e do tipo de solo. A mesorregião do Vale do Rio Doce não possui áreas preferenciais e/ou aptas ao cultivo de sequeiro da banana.

Termos para indexação: Musa spp., zoneamento, Vale do Rio Doce.

${ }^{1}$ (Paper 050-15). Received January 22, 2015. Accepted July 06, 2015.

${ }^{2}$ DSc in Phytotechnology, Professor at IFMG, São João Evangelista Campus, Av. $1^{\circ}$ de Junho, 1043, 39705-000, São João Evangelista - MG. E-mail: geovalia.santos@ifmg.edu.br

${ }^{3} \mathrm{DSc}$ in Genetics and Improvement, Professor at the Federal University of Viçosa, Department of Plant Science, Av. P H Rolfs, s / n, 36570-900, Viçosa - MG. E-mail: lasdias@ufv.br

${ }^{4} \mathrm{PhD}$ in Horticulture, Professor at the Federal University of Viçosa, Department of Plant Science, Av. P H Rolfs, s / n, 36570-900, Viçosa - MG. E-mail: ffinger@ufv.br 


\section{INTRODUCTION}

Fruit growing is an activity that has contributed significantly to national economic development, due to its capacity of employment and income generation in the agribusiness chain. This activity generates about five million jobs and accounts for $25 \%$ of national agricultural production. Brazil is the world's third largest fruit producer, with 43.6 million tons harvested in 2.2 million hectares. $53 \%$ of this production is destined for the fresh fruit market and the remaining $47 \%$ for the processed fruit. Brazilian fruit growing is practiced with tropical, subtropical and temperate fruits due to the territorial extension of the country, geographical position, different soil types and different climatic conditions. There are 500 native edible fruit species, 220 of them found in the Amazon (CNA, 2013; IBRAF, 2013).

Among the fruits produced and commercialized in the country, banana (Musa spp.) occupies a prominent position. Brazil was the sixth largest fruit producer in 2012 (SALOMÃO; SIQUEIRA, 2015). Minas Gerais accounts for $8.9 \%$ of national production, represented by 654,000 tons harvested in 41.400 hectares (IBGE, 2014). The consumer market is the applicant of the fruit to the growing urban populations. Its consumption fresh and as raw material for products such as sweets, flour, dry banana and handcraft has increased considerably in the recent years. According to FAO, Food and Agriculture Organization of the United Nations, Brazilians reached an average consumption per capita year of $29.1 \mathrm{~kg}$ of banana, two and a half times the world average consumption (FAO, 2014). This high consumption is due to the knowledge of the nutritional value of the fruit, associated to the excellent flavor and low market price.

The consumer market for bananas responds positively to the introduction of initiatives of new products and new producing regions. These new regions, when present edaphoclimatic conditions satisfying the demands of the culture, contribute to increase productivity and banana quality. In this context, the mesoregion of Vale do Rio Doce has characteristics that qualify it for the cultivation of bananas. It is the sixth largest mesoregion of the state in area, with $41,809.87 \mathrm{~km}^{2}$, and has fertile soils and high temperatures suitable for tropical fruit cultivation and long-cycle plants such as banana. In addition, the Vale do Rio Doce present to be economically stagnated requiring incentives for the establishment of banana plantations in order to improve life quality of the population and boost regional development. The knowledge of edaphoclimatic conditions of Vale do Rio Doce is important for evaluating the eventual deployment and/or establishment of commercial banana crop. Such knowledge is possible by agroclimatic zoning.

If understood the concept of Wollman and Galvani (2013), the zoning is the technique of delimitation of aptitude of growing regions as the climate and soil factors in macroclimatic and regional scales. It is used to identify and delimitate areas suitable for crops or subject to climate risks or fitodisease escape (PEREIRA et al. 2002; SENTELHAS; MONTEIRO, 2009). This is a technique of specialization of one or more combined information (SENTELHAS; MONTEIRO, 2009). In zoning, low resolution images and low quality interpolators can compromise the accuracy of the results. The interpolation of spatial data is a tool used to estimate any numeric variable in a point where its measurement was not performed. The geostatistical interpolation ponders the neighbors of the point to be estimated, in a not tendentious manner and with minimum variance to generate not biased maps (AKKALA et al., 2010). The quality of data spacialization provided by different interpolators has not received proper attention. The zoning is subject to incorporation of new study methodologies, larger number of variables, with more consistent data sets and use of interpolators that present more effective results (PEZZOPANE et al., 2012).

The Ministry of Agriculture, Livestock and Supply (MAPA) has made climate risk zoning for banana in the state of Minas Gerais, identifying municipalities able for cultivation and the planting periods with less climatic risk for the culture (BRASIL, 2010). Agroclimatic zoning have been prepared for fruit trees like avocado (ZARO et al., 2014) and macadamia nut (SCHNEIDER et al. 2012).

In this study we used the agro-climatic zoning for banana in the mesoregion of Vale do Rio Doce, in accordance with the methodology used by MAPA, adding altimetry data with the use of higher resolution satellite images.

\section{MATERIAL AND METHODS}

The mesoregion of Vale do Rio Doce has 140 municipalities allocated in the regions of Aimorés, Caratinga, Governador Valadares, Guanhães, Ipatinga, Mantena and Peçanha. It is located in the east of the state, between latitudes $18^{\circ} 49^{\prime}$ ' 12 "and $19^{\circ} 03^{\prime} 00^{\prime}$ ' South and meridians $40^{\circ} 49^{\circ}$ ' $18^{\prime}$ " and $43^{\circ} 33^{\prime} 36^{\prime \prime}$ "west of Greenwich and occupies an area of 41,791 km² (Figure 1).

For drawing up the agro-climatic zoning 
it was considered the factors: rainfall, altitude, type and class of soil aptitude, temperature and water stress. For each factor has been established the parameter for the agricultural potential of the commercial banana, according to the criteria of culture requirements (ALVES et al., 1999; PEREIRA et al., 2007; RODRIGUES et al., 2008; COELHO et al. 2009) (Table 1):

a) average temperature higher than $18^{\circ} \mathrm{C}$ and lower than $35^{\circ} \mathrm{C}$. The average of $28^{\circ} \mathrm{C}$ was considered preferential;

b) Average annual rainfall between 1,200 mm and $1,900 \mathrm{~mm}$, being $1,900 \mathrm{~mm}$ preferential;

c) altitude from 0 to $300 \mathrm{~m}$;

d) water deficit lower than $100 \mathrm{~mm}$;

e) soils Groups I and II (Table 2).

In accordance with the above criteria were defined classes of aptitude for cultivation: preferential, suitable, suitable with irrigation, suitable with soil management, restricted by altitude, restricted by soil and inept (Tables 1 and 2). These classes allow you to identify suitable and inapt regions and with specific restrictions per variable evaluated.

Information on thermal conditions was obtained from the weather stations of the National Institute of Meteorology (INMET) located in the municipalities of Aimorés and Caratinga, with historical series of 22 years. However, considering the lack of information on meteorological data it was necessary to use models such as multiple regression equations (SEDIYAMA; MELO JUNIOR, 1998; MEDEIROS et al., 2005). For sites deprived of information, it was estimated the average annual temperature by means of regression equations, using the geographical coordinates and the altitude of the desired point. Thus it was also used data from meteorological stations of Hydrological Information System (HIDROWEB) of the National Water Agency (ANA) which, together with INMET stations totaled 102 points, complementing the spatial data.

The altimetry data were obtained from the digital elevation model (DEM) generated from ASTER images (Advanced Spaceborne Thermal Emission Reflection Radiometer) of October 2011, whose resolution has $30 \mathrm{~m}$ with vertical error of 7 to $14 \mathrm{~m}$, using geographic projection system WGS84 (World Geodetic system) (ASTER, 2013).

Rainfall data of the mesoregion of Vale do Rio Doce were obtained from Guimarães et al. (2004) and ANA, resulting in 51 historical series. The data series of the ANA's HIDROWEB system were selected on the basis of the collection duration (over 30 years), of its continuity and of the result of the consistency analysis.
To calculate the soil water deficit for banana plant it was used the normal hydric balance proposed by Thornthwaite and Mather (1955), from the spreadsheet developed by Rolim et al. (1998). It was taken as the amount of available water capacity in the soil (AWC) $100 \mathrm{~mm}$, to be considered an average value for the culture according to Pereira et al. (2002). The normal water balance resulted from the joint analysis of temperature and average monthly precipitation of each station considered. The monthly average rainfall data were also obtained from the INMET weather stations and stations used to estimate the average monthly temperature.

Information on soil types have been acquired from the Integrated Use Program of Geoprocessing from the Government of Minas Gerais (Geominas). The Geographic Information System (GIS) used to generate the maps and perform their crossing was the ArcGIS version 10, with kriging interpolation methods for the generation of temperature maps and IDW (Inverse Distance Weighted) for the remaining maps. GIS and spatial interpolation techniques may be revised in Akkala et al. (201

\section{RESULTS AND DISCUSSION}

Considering the demands of the culture, the optimum temperature is $28^{\circ} \mathrm{C}$, with a minimum of 18 ${ }^{\circ} \mathrm{C}$ and maximum $35^{\circ} \mathrm{C}$. The banana tree should not be grown in areas with minimum temperature below $15^{\circ} \mathrm{C}$, as there is paralysis of their metabolic activity or above $35{ }^{\circ} \mathrm{C}$ when occurs the paralyzation of its development by dehydration of the leaves (ALVES et al., 1999; PEREIRA et al., 2007; RODRIGUES et al., 2008; COELHO et al. 2009). It is verified that the mesoregion of Vale do Rio Doce has, throughout its length, thermal conditions favorable to the cultivation of banana tree to present annual average temperatures within the required range $\left(18^{\circ}\right.$ to 35 ${ }^{\circ} \mathrm{C}$ ) for the good development of crops (Figure 2). Regarding the altitude, the range from 0 to $300 \mathrm{~m}$ was considered ideal for maximum productivity of banana tree (ALVES et al., 1999; PEREIRA et al., 2007; RODRIGUES et al., 2008; COELHO et al. 2009). It is known that in regions with altitude above $300 \mathrm{~m}$ the banana tree increases the duration of the production cycle. It is noted that more than $30 \%$ of the area of the mesoregion of Vale do Rio Doce $\left(12,832 \mathrm{~km}^{2}\right)$ has altitudes within the ideal range for growing (Figure 3). More than $65 \%$ of the mesoregion area $\left(27,532 \mathrm{~km}^{2}\right)$ presents altitudes within the acceptable range (between 0 and $900 \mathrm{~m}$ ) for banana production, and only $3.4 \%$ of the area 
has altitude above $900 \mathrm{~m}$, considered inappropriate (Table 1, Figure 3).

Regarding precipitation, the culture requires an average of 1,900 $\mathrm{mm}$ well distributed throughout the year. The consumption of water by the plant is high and constant, due to its morphology and hydration of the tissues. Annual rainfall below 1,200 $\mathrm{mm}$ restricts the cultivation of banana tree, as difficult or prevents the release of the inflorescence (ALVES et al., 1999; PEREIRA et al., 2007; RODRIGUES et al., 2008; COELHO et al. 2009). Thus, the mesoregion of Vale do Rio Doce have $34.3 \%$ of its area $\left(14,332.8 \mathrm{~km}^{2}\right)$ suitable for cultivation having average annual rainfall within the acceptable range $(1,200-1,900 \mathrm{~mm})$ for fruit production and $65.7 \%$ of its area $\left(27,456.5 \mathrm{~km}^{2}\right)$ unsuited to cultivation to present annual average rainfall below 1,200 mm (Figure 4).

For water deficit, the annual limit considered acceptable for the banana cultivation is $100 \mathrm{~mm}$. The deficit above $100 \mathrm{~mm}$ reduces plant productivity and the quality of its fruit (ALVES et al., 1999; PEREIRA et al., 2007; RODRIGUES et al., 2008; COELHO et al. 2009). Thus, it is observed that the mesoregion of Vale do Rio Doce has no favorable hydric conditions to be out of the acceptable limit of water deficiency (Figure 5). Throughout the extent of the mesoregion, water deficiency ranges from $116 \mathrm{~mm}$ (West and South) to $379 \mathrm{~mm}$ (Midwest and Northeast), annual amounts considered high for banana production in unirrigated conditions. In this sense, the banana plantation in the mesoregion of Vale do Rio Doce should only be recommended with supplementary irrigation.

Latosolic soils are suitable for banana production to be well-drained, deep (over 100 $\mathrm{cm})$, medium texture to clayish, well-structured, permeable, fertile, neutral to slightly acidic $\mathrm{pH}$, no risk of flooding and salinity free (SALOMÃO; SIQUEIRA, 2015). On the other hand, the shallow, rocky soils, as Neosoil and rocky outcrops are inadequate. The mesoregion of Vale do Rio Doce has more than $97 \%$ of its area suitable for banana cultivation by having Yellow, Red, Yellow and Red Latosols, Red Yellow Podzolic and Red Nitosol (Figure 6). Only $2.8 \%$ of the mesoregion are considered unsuitable for the banana crop, they are Neosoil or rocky outcrop, both inapt for culture.

From the suitability maps generated for each variable considered in the study, it was obtained agro-climatic zoning map for the banana in the mesoregion of Vale do Rio Doce (Figure 7). In it you can see that the mesoregion has $28.7 \%$ of the area suitable for the cultivation of bananas, since if practiced with irrigation. This area of 11,000 $\mathrm{km}^{2}$ or 1.1 million ha is 27 times larger than the current area planted with banana throughout the state of Minas Gerais. About $71.3 \%$ of the area is considered inappropriate to the cultivation of bananas. This is due to the altitude related to the type of mesoregion soil. For this last area, techniques are recommended as liming, fertilization and irrigation (more installments) for inapt soils (Neosoil). For restricted soils (Cambisoils), besides liming and fertilization is recommended the contour lines and rows of vegetation to allow banana production.

In relation to areas with unsuitable altitudes to banana cultivation (above $900 \mathrm{~m}$ ) it is recommended the evaluation of the cost-benefit of the use of protected environment for commercial production. Banana growers have available several lines of credit, both for investments in infrastructure as well as for costing of the implanted culture. In some regions of the Canary Islands (Spain) it was observed that the weight of banana bunches increased by $20 \%$ under protected cultivation, compared to cultivation in the open sky (GALÁN SAÚCO et al., 1998). Good banana yields are obtained in protected crops also in Morocco (JANICK; AIT-OUBAHOU, 1989). Thus, it is necessary to evaluate whether the increase in productivity with the banana crop in a protected environment justifies the investment made in the activity. 


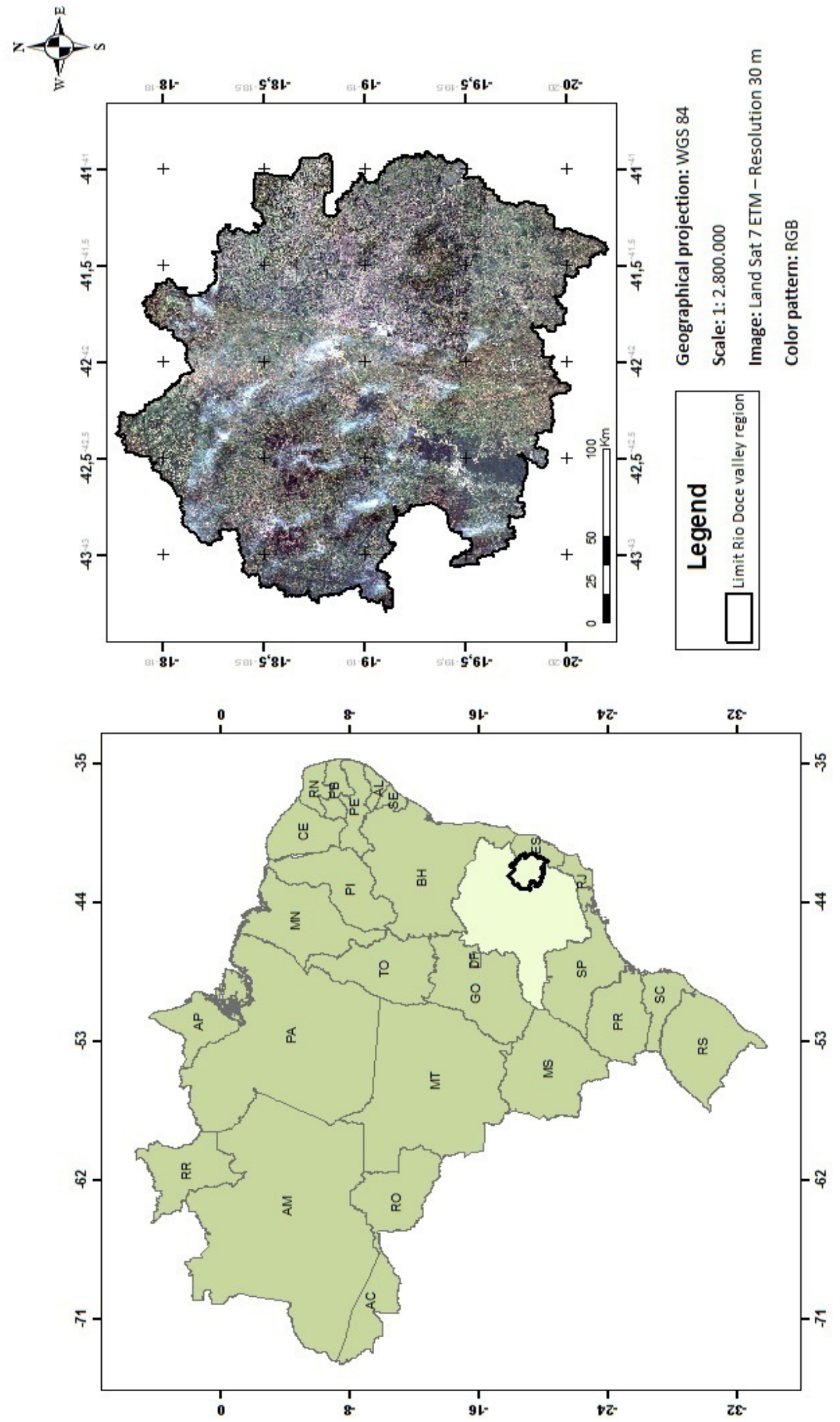

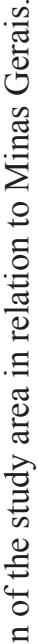

.

รี

F

సี

:ี

:

윙

$\simeq$

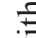

$\sum$

范

를

फ

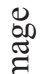

$\Xi$

雚

$\sum$

占 
TABLE 1 - Classes of aptitude for banana cultivation.

\begin{tabular}{lccccc}
\hline Classes of Aptitude & $\begin{array}{c}\text { Annual average } \\
\text { temperature } \\
\left({ }^{\circ} \mathrm{C}\right)\end{array}$ & $\begin{array}{c}\text { Annual water } \\
\text { deficiency }(\mathrm{mm})\end{array}$ & $\begin{array}{c}\text { Annual } \\
\text { average } \\
\text { rainfall } \\
(\mathrm{mm})\end{array}$ & $\begin{array}{c}\text { Altitude } \\
(\mathrm{m})\end{array}$ & Soils \\
\hline Preferential & 28 & $<100$ & 1900 & $0-300$ & I \\
Suitable & $18-35$ & $<100$ & $1200-1900$ & $0-900$ & II \\
Suitable with irrigation & $18-35$ & $>100$ & $<1200$ & $0-900$ & II \\
Suitable with soil management & $18-35$ & $<100$ & $1200-1900$ & $0-900$ & III \\
Restricted by altitude & $18-35$ & $<100$ & $1200-1900$ & $>900$ & II \\
Restricted by soil & $18-35$ & $<100$ & $1200-1900$ & $0-900$ & IV \\
Inept & $<15 \mathrm{e}>35$ & $>100$ & $<1200$ & $>900$ & IV \\
\hline
\end{tabular}

TABLE 2 - Classes of soil aptitude for banana cultivation.

\begin{tabular}{ccc}
\hline Group & $\begin{array}{c}\text { Classes of } \\
\text { Aptitude }\end{array}$ & Soils \\
\hline
\end{tabular}

Oxisol Eutroferric and Eutrophic Red Yellow Eutrophic Alfisoil, Luvisol Haplic,

I Preferred soils Cambisol, Chernossolos and Fluvic Neossols Eutrophic, non-salty, non-sodic and well drained.

Rhodic Eutrophic Red Yellow Eutrophic Alfisoil, Luvisol Haplic, Cambisol, Chernosol Argilúvico and Neosoil Fluvic Eutrophic, non-salty, non-sodic and well drained, Distroferric Red Latosol and dystrophic Red Yellow Latosol and

II Suitable soils Yellow, Red Nitosol Dystroferric Ultisol dystrophic and Yellow, Cambisol, Vertisol, Chernosol Argilúvico, Fluvic Neossols Dystrophic and or poorly drained, Gleysol, Organosols and Vertisols.

Quartzarenic Neosols Yellow Dystrophic Red Latosol (medium texture) and Iron III Restricted soils Quadrangle, Luvisol and Argisol shallow, Chernosol Rêndzico, Luvisol Chromic shallow Orthic, shallow Cambisol, Neosoil, Spodosol and some Planosols with thick surface horizons (over $50 \mathrm{~cm}$ ).

IV Inapt soil Litholic Neosols, Argissolos shallow and / or stony, Cambisol shallow and / or stony, Luvisol Chromic Orthic shallow, Planosol and Gleysol. 


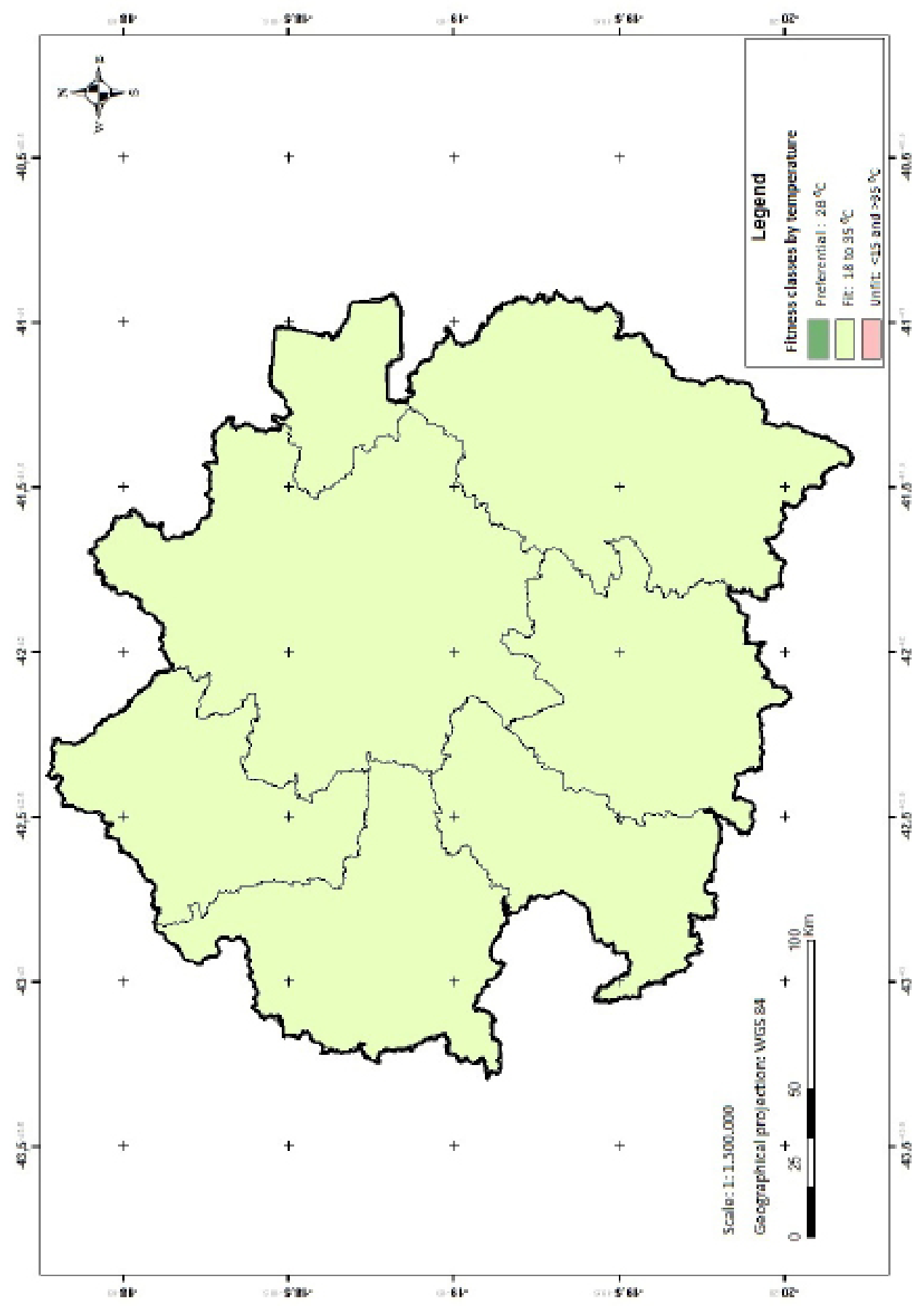

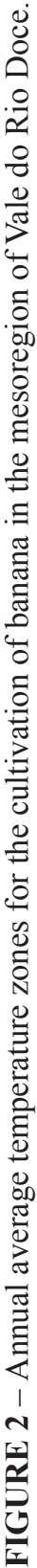




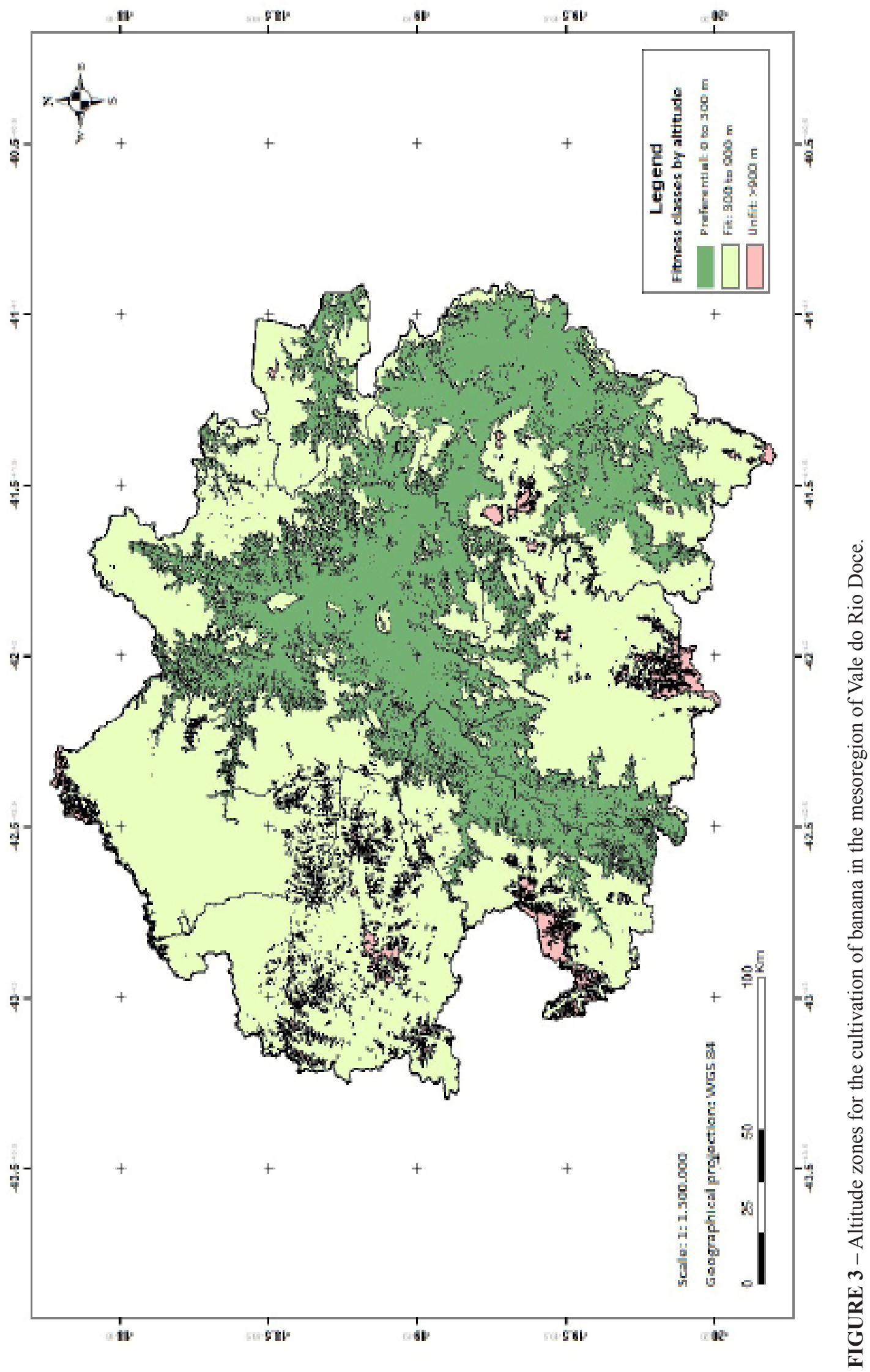




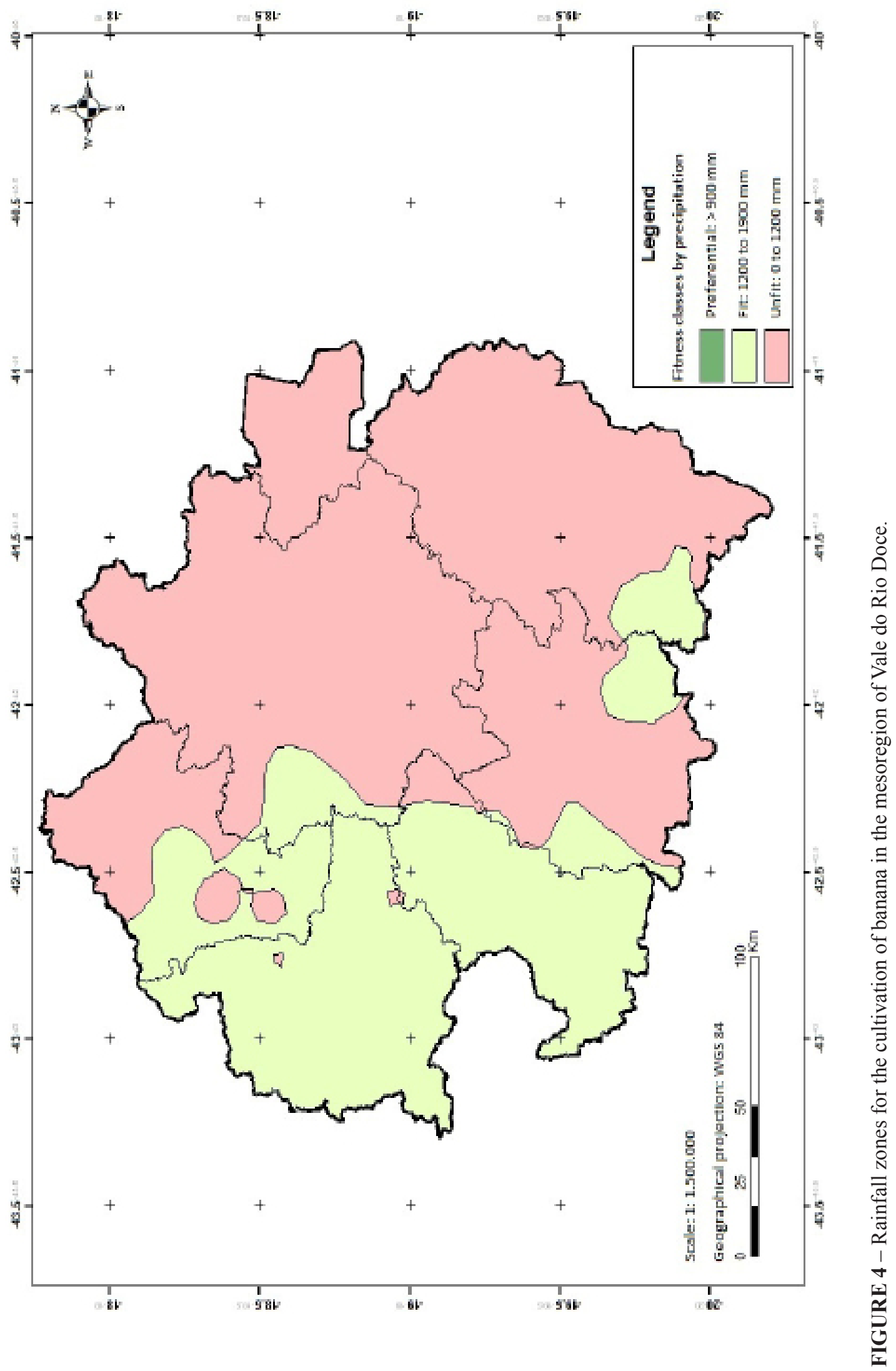




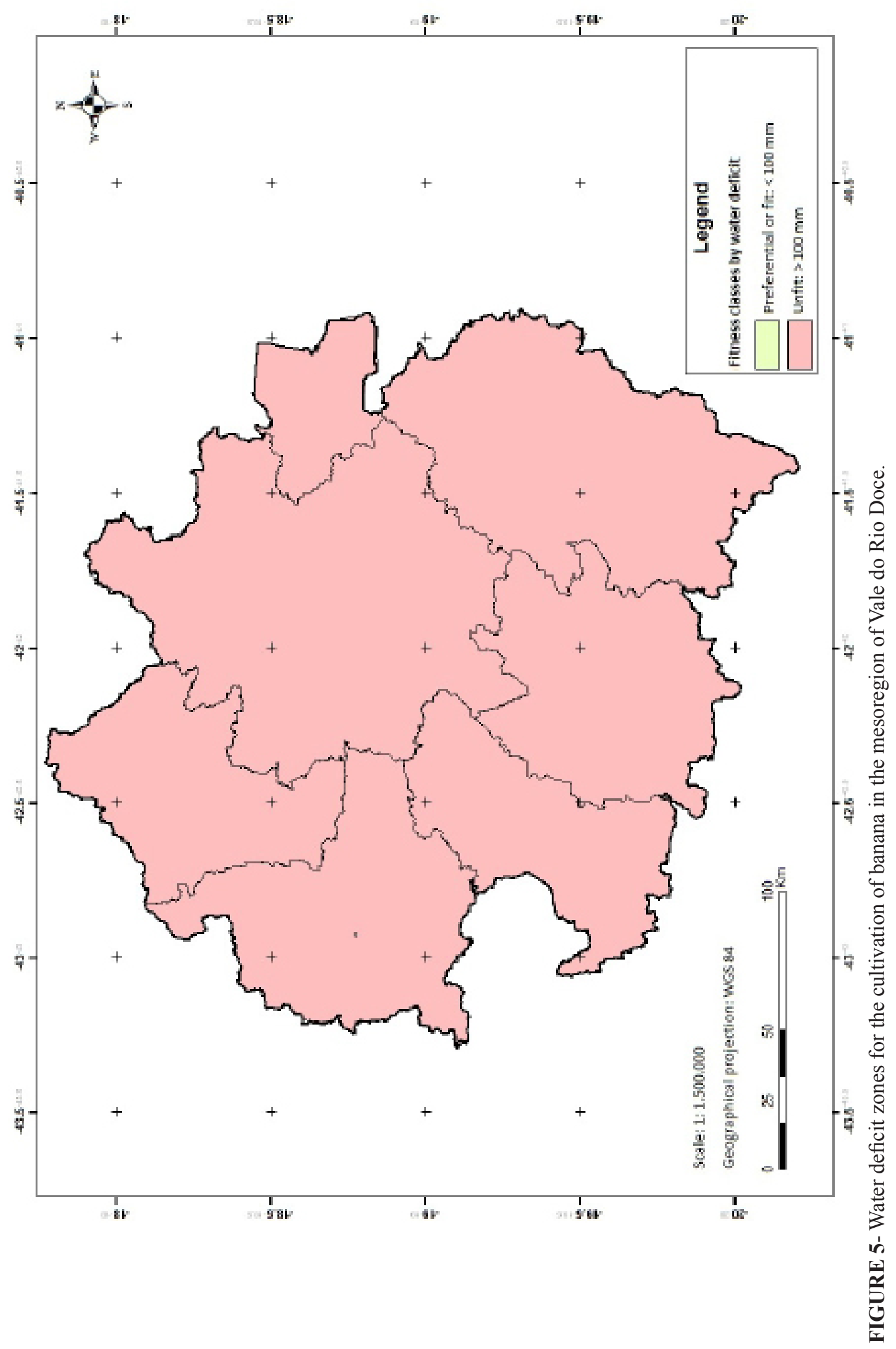




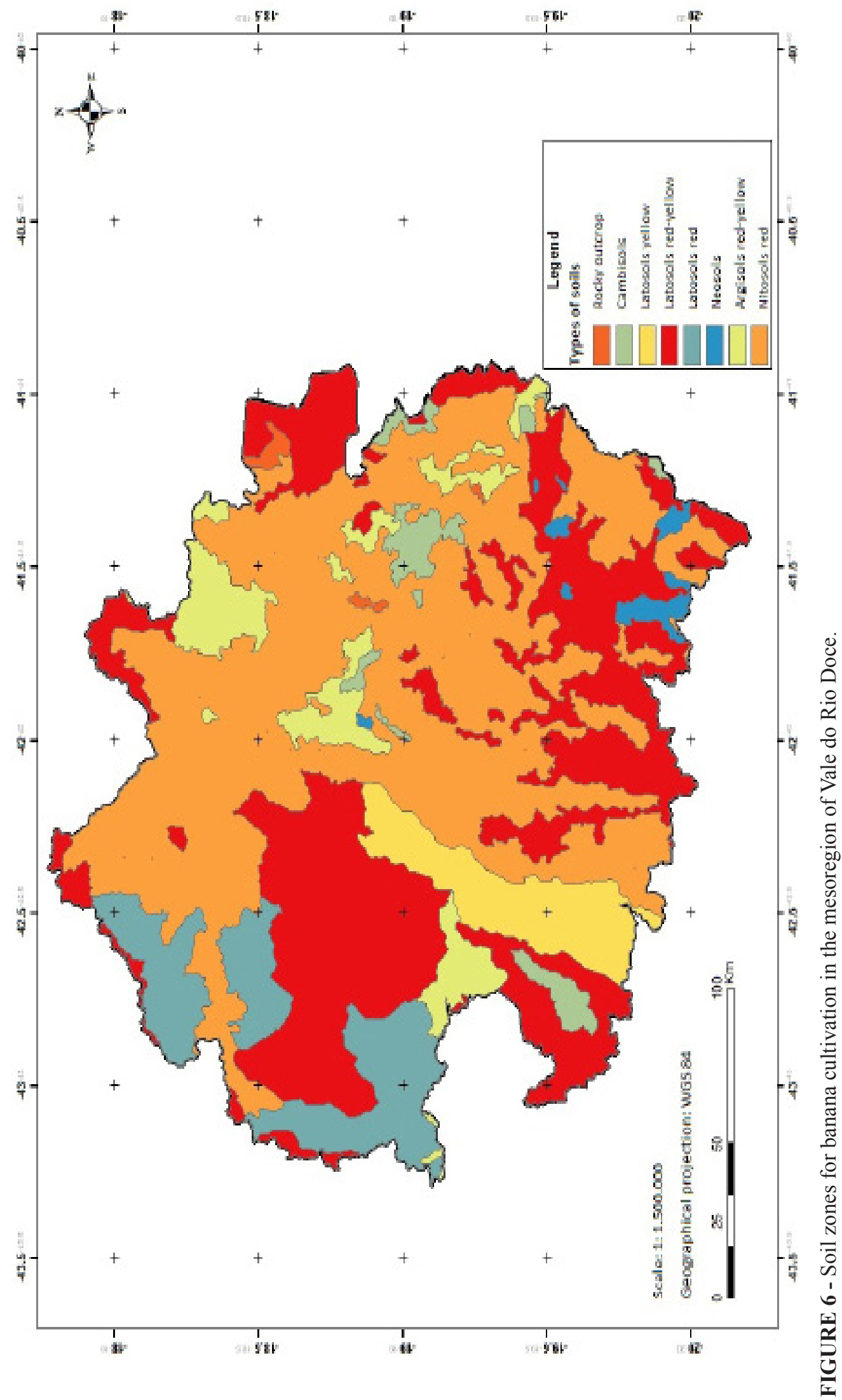




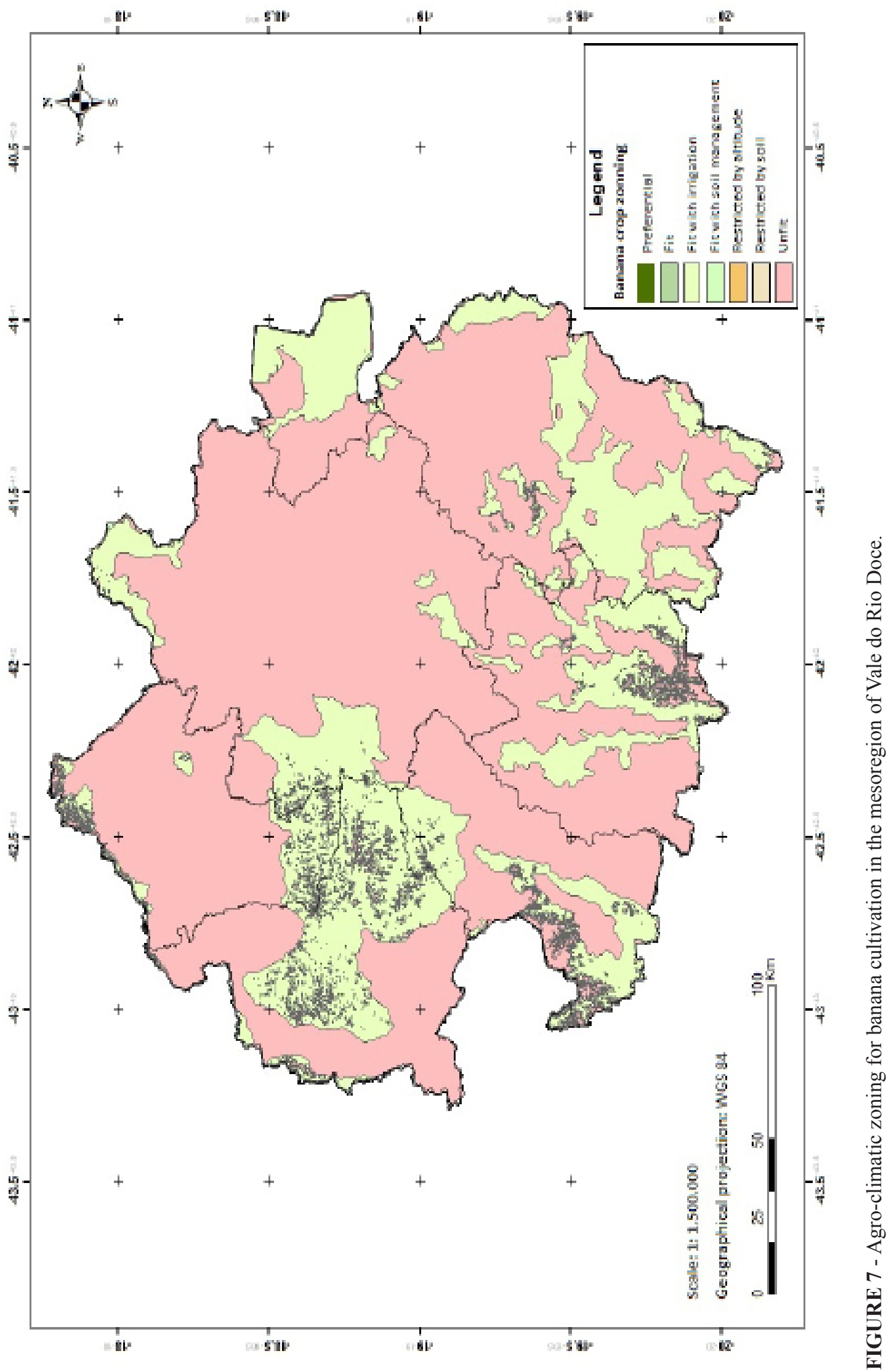




\section{CONCLUSION}

The agro-climatic zoning for banana plants in the mesoregion of Vale do Rio Doce has allowed the conclusion that $28.7 \%$ of the area comprising the micro-regions of Guanhães, Mantena and Aimorés, has favorable conditions for irrigated cultivation.

\section{ACKNOWLEDGEMENTS}

We would like to thank the IFMG by the support given to the research, to CAPES for financial support, to the INMET and ANA for the availability of data on the Internet; and to the Federal University of Viçosa for the PhD opportunity.

\section{REFERENCES}

AKKALA, A.; DEVABHAKTUNI, V.; KUMAR, A. Interpolation techniques and associated software for environmental data. Environmental Progress \& Sustainable Energy, Hoboken, v.29, n.2, p. 134$141,2010$.

ALVES, E.J.; OLIVEIRA, M.A.; DANTAS, J.L.L.; OLIVEIRA, S.L. Exigências climáticas. In: ALVES, E.J. (Org.). A cultura da banana: aspectos técnicos, socioeconômicos e agroindústrias. 2.ed. Brasília: Embrapa, 1999. v.1, cap.2, p.35-46.

ASTER - Advanced Spaceborne Thermal Emission Reflection Radiometer. Jet propulsion laboratory: California Institute of Technology, 2013. Disponível em: <http://asterweb.jpl.nasa.gov/index.asp>. Acesso em: 25 ago. 2013.

BRASIL. Ministério da Agricultura, Pecuária e Abastecimento. Secretaria de Política Agrícola/ Departamento de Gestão de Risco Rural. Portaria $\mathrm{n}^{\circ}$ 268, de 18 de agosto de 2010. Brasília, 2010. 5p.

CNA - Confederação da Agricultura e Pecuária do Brasil. Balanço 2013 - perspectivas 2014. Brasília: CNA, 2013. 121p.

COELHO, E.F.; DONATO, S.L.R.; ANDRADE NETO, T.M. Banana. In: MONTEIRO, J.E.B.A. (Org.). Agrometeorologia dos cultivos. O fator meteorológico na produção agrícola. Brasília: INMET, 2009. p.321-322.
EMBRAPA - Centro Nacional de Pesquisa de Solos. Sistema brasileiro de classificação de solos. 2.ed. Rio de Janeiro: Embrapa Solos, 2006.

FAO - Food and Agriculture Organization of the United Nations. FAOSTAT: statistics database. Disponível em: $\leq$ http://faostat3.fao.org/home/index. html\#DOWNLOAD>. Acesso em: 28 jun. 2014.

GALÁN SAÚCO, V.; CABRERA CABRERA, J.; HERNÁNDEZ DELGADO, P.M.; RODRÍGUEZ PASTOR, M.C. Comparison of protected and openair cultivation of Grande Naine and Dwarf Cavendish bananas. Acta Horticulturae, The Hague, v.490, p.247-259, 1998.

GUIMARÃES, D.P.; REIS, R.J. dos; SANS, L.M.A. Espacialização das chuvas em Minas Gerais. In: CONGRESSO BRASILEIRO DE METEOROLOGIA, 13., 2004, Fortaleza. Anais...

IBGE - Instituto Brasileiro de Geografia. Canais: sidra. Disponível em: $<\mathrm{http}$ ://www.sidra.ibge.gov. $\mathrm{br} / \mathrm{bda} /$ tabela $/$ listabl.asp? $\mathrm{z}=\mathrm{t} \& \mathrm{o}=11 \& \mathrm{i}=\mathrm{P} \& \mathrm{c}=854 \mathrm{P}$. Acesso em: 14 nov. 2014.

IBRAF - Instituto Brasileiro de Frutas. Panorama da cadeia produtiva das frutas em 2012 e projeções para 2013. Brasília: IBRAF, 2013. 127p.

JANICK, J.; AIT-OUBAHOU, A. Greenhouse production of banana in Morocco. HortScience, Alexandria, v.24, p.22-27, 1989.

MEDEIROS, S.S.; CECÍLIO, R.A.; MELO JÚNIOR, J.C.F. de; SILVA JUNIOR, J.L.C. da. Estimativa e espacialização das temperaturas do ar mínimas, médias e máximas na região Nordeste do Brasil. Revista Brasileira de Engenharia Agrícola e Ambiental, Campina Grande, v.9, n.2, p.247-255, 2005.

PEREIRA,A.R.;ANGELOCCI, L.R.; SENTELHAS, P.C. Agrometeorologia: fundamentos e aplicações práticas. Guaíba: Agropecuária, 2002. 478p.

PEREIRA, L.V.; FRÁGUAS, J.C.; SILVA, S.O.; CORDEIRO, Z.J.M.; SILVA, C.R. de R. Banana (Musa spp.). In: PAULA JÚNIOR, T.J.; VENZON, M. 101 culturas - manual de tecnologias agrícolas. Belo Horizonte: EPAMIG, 2007. p.113-124. 
PEZZOPANE, J.E.M.; CASTRO, F.S.; PEZZOPANE, J.R.M.; CECÍLIO, R.A. Agrometeorologia: aplicações para o Espírito Santo. Vitória: CAUFES, 2012. v.1, 174p.

RODRIGUES, M.G.V.; DIAS, M.S.C.; RUGGIERO, C.; LICHTEMBERG, L.A. Planejamento, implantação e manejo do bananal. Informe Agropecuário, Belo Horizonte, v.29, n.245, p.1424, 2008.

ROLIM, G.S.; SENTELHAS, P.C.; BARBIERI, V. Planilhas no ambiente EXCEL para os cálculos de balanços hídricos: normal, sequencial, de cultura e de produtividade real e potencial. Revista Brasileira de Agrometeorologia, Santa Maria, v.63, n.1, p.133$137,1998$.

SALOMÃO, L.C.C.; SIQUEIRA, D.L. de. Cultivo da bananeira. Viçosa: Editora UFV, 2015. 109p.

SCHNEIDER, L.M.; ROLIM, G.de S.; SOBIERAJSKI, G.da R.; PRELA-PANTANO, A.; PERDONÁ, M.J. Zoneamento agroclimático de nogueira-macadâmia para o Brasil. Revista Brasileira de Fruticultura, Jaboticabal, v.32, n.1, p.515-524, 2012.
SEDIYAMA, G.C.; MELO JÚNIOR, J.C.F. Modelos para estimativas das temperaturas normais mensais médias, máximas, mínimas e anual no Estado de Minas Gerais. Revista Engenharia na Agricultura, Viçosa, MG, v.6, n.1, p.57-61, 1998.

SENTELHAS, P.C.; MONTEIRO, J.E.B.A. Agrometeorologia dos cultivos. In: MONTEIRO, J.E.B.A. (Org.). Agrometeorologia dos cultivos. O fator meteorológico na produção agrícola. Brasília: INMET. 2009. p.1-12.

THORNTHWAITE, C.W.; MATHER, J.R. The water balance. Centerton: Drexed Institute of Technology, 1995. 104p.

WOLLMANN, C.A.; GALVANI, E. Zoneamento agroclimático: linhas de pesquisa e caracterização teórica-conceitual. Sociedade \& Natureza, Uberlândia, v.25, n.1, p.179-190, 2013.

ZARO, G.C.; RICCE, W. da S.; CARAMORI, P.H.; CARVALHO, S.L.C.; VICENTINI, M.E. Zoneamento agroclimático para a cultura do abacateiro no estado do Paraná. Revista Brasileira de Fruticultura, Jaboticabal, v.36, n.2, p.363-372, 2014. 